JURNAL ILMIAH KEBIDANAN IMELDA

Vol.6, No.2, September 2020, pp. 88-91

ISSN: 2597-7180 (Online),2442-8116 (Print)

http://jurnal.uimedan.ac.id/index.php/JURNALKEBIDANAN

\title{
FAKTOR-FAKTOR YANG BERHUBUNGAN DENGAN KEJADIAN INTRA UTERINE FETAL DEATH (IUFD)
}

\author{
Elvalini Warnelis Sinaga \\ Universitas Imelda, Indonesia
}

\begin{tabular}{l}
\hline Article Info \\
\hline Article history: \\
Received Sep 23, 2019 \\
Revised Sep 24, 2020 \\
Accepted Sep 25, 2020 \\
\hline
\end{tabular}

\section{Keywords:}

Mother's age

Gestational age

$\mathrm{Hb}$ level

IUFD

\begin{abstract}
Intra Uterine Fetal Death or IUFD is a condition where a fetus dies in the womb after 20 weeks of pregnancy. Some cases of IUFD cannot be prevented. To reduce the risk, health workers can be aware of the cause and take appropriate preventive measures. This study aims to determine the factors associated with the incidence of intrauterine fetal death at Imelda Hospital, Medan. The method used in this research is descriptive analytic research method with cross sectional approach. The total sample of 90 people consisted of 45 people with cases of Intra Uterine Fetal Death and 45 people who did not experience Intra Uterine Fetal Death as controls. The research instrument used was a check list. Data analysis used the Chi-square test. The results of the Chi-square test analysis of the relationship between maternal age and the incidence of IUFD obtained the value of $\rho$ value $=0.594(\rho>$ 0.05 ), which means that there is no significant relationship between maternal age and the incidence of IUFD, gestational age and the incidence of IUFD, the value of $\rho$ value $=1,000$ is obtained. $(\rho>0.05)$ means that there is no significant relationship between gestational age and the incidence of IUFD. While the results of the Chi-square test analysis of the relationship between $\mathrm{Hb}$ levels and the incidence of IUFD, the value of $\rho$ value $=0.010(\rho<0.05)$ was found, meaning that there was a significant relationship between $\mathrm{Hb}$ levels and the incidence of IUFD. From the results of the study, there was no relationship between maternal age and gestational age with the incidence of Intra Uterine Fetal Death, and there was a relationship between $\mathrm{Hb}$ levels and the incidence of Intra Uterine Fetal Death.
\end{abstract}

This is an open access article under the CC BY-SAlicense.

\section{Corresponding Author:}

Elvalini Warnelis Sinaga,

Program Studi D-III Kebidanan,

Universitas Imelda Medan,

Jl. Bilal No. 52 Kelurahan Pulo Brayan Darat I Kecamatan Medan Timur, Medan - Sumatera Utara.

Email: geoffreygopaz@gmail.com

\section{INTRODUCTION}

IUFD merupakan salah satu penyebab kematian perinatal. IUFD termasuk masalah angka kematian bayi (AKB) yang merupakan salah satu indikator yang penting untuk menilai tingkat kesejahteraan suatu negara, kematian janin dalam kandungan dapat disebabkan oleh beberapa faktor yaitu faktor ibu, faktor janin, dan faktor plasenta. Faktor ibu meliputi umur, kehamilan post term (> 42 minggu) dan penyakit yang diderita oleh ibu seperti anemia, preeklampsia, eklampsia, diabetes mellitus, rhesus iso- imunisasi, infeksi dalam kehamilan, Ketuban Pecah Dini (KPD), ruptura uteri, hipotensi akut ibu (Saifuddin, A. B, 2010).

Janin bisa juga mati di dalam kandungan (IUFD) karena beberapa faktor antara lain gangguan gizi dan anemia dalam kehamilan, hal tersebut menjadi berbahaya karena suplai makanan yang di konsumsi ibu tidak mencukupi kebutuhan janin. Sehingga pertumbuhan janin terhambat dan dapat mengakibatkan 
kematian. Begitu pula dengan anemia, karena anemia adalah kejadian kekurangan Fe maka jika ibu kekurangan Fe dampak pada janin adalah irefersibel.

Berdasarkan Data Profil Dinas Kesehatan propinsi Sumatera Utara tahun 2013, Angka Kematian Neonatal (AKN) berjumlah 456 kasus kematian, dan kejadian lahir mati (prenatal death) berjumlah 312 kasus kematian, yang termasuk di dalamnya kejadian di kota Medan berjumlah 128 kasus kematian.

Menurut penelitian yang berkaitan dengan Intra Uterine Fetal Death (IUFD) menyatakan usia maternal merupakan salah satu faktor risiko terjadinya intrauterine fetal death. Kejadian intrauterine fetal death meningkat pada usia maternal $<20$ tahun dan $>30$ tahun. Hal ini disebabkan karena menurunnya perfusi uteroplasenta, komplikasi penyakit kronis selama kehamilan dan mekanisme lain yang belum jelas (Luqyana et al., 2017).

Data yang penulis dapatkan tanggal 15 Juli 2020 dari data rekam medik di RSU Imelda Medan dari tahun 2015 sampai tahun 2019 mengalami peningkatan. Pada tahun 2015 proporsi kejadian IUFD sebanyak 11 kasus $(2,2 \%)$ dari 789 persalinan. Pada tahun 2016 proporsi kejadian IUFD menurun menjadi 14 kasus $(1,6 \%)$ dari 987 persalinan. Dan pada tahun 2017 kembali naik dengan proporsi kejadian sebanyak kasus $(2,1 \%)$ dari 675 persalinan. Faktor penyebab kejadian IUFD yang terjadi di RSU Imelda umumnya terjadi karena faktor maternal, fetal dan placenta. Faktor maternal terdiri dari umur ibu, umur kehamilan dan penyakit yang dialami oleh ibu seperti KPD, diabetes melitus, eklampsi, pre eklampsi sedangkan faktor fetal terdiri dari kelainan kongenital dan kehamilan kembar. Faktor placenta terdiri dari lilitan tali pusat,solusio placenta dan plasenta previa.

Upaya untuk mencegah terjadinya keatian janin dalam kandungan yaitu dengan rutin melakukan kunjungan ante natal care. Kunjungan dapat dilakukan minimal 1 kali selama trimester 1, 1 kali selama trimester 2, dan 2 kali pada trimester 3. Peningkatan pengetahuan ibu hamil dapat diupayakanmelalui penyuluhan kesehatan tentang tanda bahaya pada kehamilan seperti perdarahan jalan lahir, pembengkakan muka, kaki dan jari kaki, sakit kepala berat, penglihatan kabur, keluar cairan banyak dari jalan lahir, dan pergerakan janin berkurang. Konsumsi makanan dengan nilai gizi yang baik untuk mencegah terjadinya anemia, abortus, partus prematurus, kematian janin dalam rahim. Penelitian ini bertujuan untuk mengetahui faktor-faktor yang berhubungan dengan kejadian Intra Uterine Fetal Death di RSU Imelda Medan.

\section{RESEARCH METHOD}

Metode penelitian ini adalah deskriptif analitik dengan pendekatan cross sectional. Penelitian ini untuk mengetahui faktor-faktor yang berhubungan dengan kejadian IUFD di RSU Imelda. Variabel bebas dan terikat dari penelitian ini antara lain: umur ibu, umur kehamilan, dan kadar hemoglobin sebagai variabel bebas, dan kejadian IUFD sebagai variabel terikat. Populasi dalam penelitian ini adalah semua ibu hamil yang melahirkan pada bulan Januari sampai Desember tahun 2019 di RSU Imelda Medan. Sampel pada penelitian ini adalah 90 orang dibagi dalam kasus ibu hamil yang melahirkan dengan IUFD sebanyak 45 orang, dan kontrol yaitu ibu hamil yang melahirkan bayi hidup (tidak IUFD) sebanyak 45 orang di RSU Imelda Medan. Instrument penelitian menggunakan check list dan data akan dianalisis dengan uji chi square.

\section{RESULTS AND ANALYSIS}

\subsection{Hasil}

\section{Gambaran Umum Responden}

Berdasarkan distribusi umur ibu menunjukkan presentase terbesar adalah umur 20-35 berjumlah 43 $(47,8 \%)$, pada umur kehamilan menunjukkan presentase terbesar yaitu pada umur kehamilan $<42$ minggu berjumlah 81 (90\%), dan pada kadar $\mathrm{Hb}$ menunjukkan presentase terbesar pada kadar $\mathrm{Hb} \geq 11$ gr\% berjumlah $62(68,9 \%)$.

Tabel 1. Hubungan Umur Ibu, Umur Kehamilan, Kadar Hb Dengan Kejadian IUFD

\begin{tabular}{|c|c|c|c|c|c|c|c|}
\hline \multirow[t]{3}{*}{ Variabel } & \multicolumn{4}{|c|}{ Kejadian IUFD } & \multirow[t]{3}{*}{ Total } & \multirow[t]{3}{*}{$\%$} & \multirow[t]{3}{*}{$\mathrm{P}$} \\
\hline & \multicolumn{2}{|c|}{ IUFD } & \multicolumn{2}{|c|}{ Tidak IUFD } & & & \\
\hline & $\mathbf{N}$ & $\%$ & $\mathbf{N}$ & $\%$ & & & \\
\hline \multicolumn{8}{|l|}{ Umur Ibu } \\
\hline$<20$ dan $>35$ tahun & 23 & 51,1 & 20 & 66,7 & 43 & 47,8 & 0,594 \\
\hline $20-35$ tahun & 22 & 48,9 & 25 & 33,3 & 37 & 52,2 & \\
\hline \multicolumn{8}{|l|}{ Umur kehamilan } \\
\hline$\geq 42$ minggu & 4 & 8,9 & 5 & 11,1 & 9 & 10 & 1,000 \\
\hline$<42$ minggu & 41 & 91,1 & 40 & 88,9 & 81 & 90 & \\
\hline \multicolumn{8}{|l|}{ Kadar Hb } \\
\hline$<11$ gr $\%$ & 12 & 26,7 & 16 & 35,5 & 28 & 31,1 & 0,010 \\
\hline$<11$ gr $\%$ & 33 & 73,3 & 29 & 64,5 & 62 & 68,9 & \\
\hline
\end{tabular}

Tabel 1 diatas menunjukkan tidak adanyahubungan antara umur ibu dan umur kehamilan ibu dengan kejadian IUFD, yang dapat dibuktikan dengan hasil uji statistik yaitu nilai $\rho=0,594$ untuk umur ibu dan $\rho=$ 1,000, untuk umur kehamilan ibu, sedangkankadar $\mathrm{Hb}$ mempunyai hubungan yang signifikan dengan 
kejadian IUFD. Berdasarkan dari hasil uji statistik chi-square dengan tingkat kepercayaan 95\% (derajat kemaknaan $\alpha=0,05$ ), nilai $\mathrm{p}=0,010<0,05$.

\subsection{Pembahasan}

\section{Hubungan Faktor Umur Ibu Dengan Kejadian IUFD}

Berdasarkan hasil analisa penelitian menurut umur ibu, dari 90 sampel yang terbagi dalam kejadian IUFD 45 orang menunjukkan untuk umur tidak berisiko (20-35 tahun) berjumlah 22 orang (48,9\%) dan untuk umur berisiko berjumlah 23 orang $(51,1 \%)$. Dalam hal inimenunjukkan kategori umur berisiko lebih banyak dibandingkan dengan umur tidak berisiko. Pada umur ibu yang masih muda $(<20$ tahun $)$ organ-organ reproduksi dan emosi belum cukup matang sehingga mengakibatkan rasa takut terhadap kehamilan dan persalinan dikarenakan diusia tersebut ibu belum siap untuk hamil. Kehamilan diusia tua (> 35 tahun) menimbulkan kecemasan terhadap kehamilan dan persalinan serta alat-alat reproduksi ibu yang fungsinya mulai menurun. Sedangkan untuk kejadian tidak IUFD 45 orang menunjukkan untuk umur tidak berisiko (20-35 tahun) berjumlah 25 orang (33,3\%) dan umur berisiko ( $<20$ dan $>35$ tahun) berjumlah 20 orang $(66,7 \%)$. Hal ini menunjukkan kategori umur tidak berisiko lebih banyak dibandingkan dengan umur berisiko. Umur 20-35 tahun merupakan usia produktif bagi seseorang. Umur 20-35 tahun adalah relative paling aman dari segi reproduksi sehat dimana seorang ibu bisa mengandung dengan aman apabila mendapat pemeliharaan yang baik selama mengandung.

\section{Hubungan Faktor Umur Kehamilan Dengan Kejadian IUFD}

Berdasarkan hasil analisa penelitian menurut umur kehamilan, dari 90 sampel, dengan kejadian IUFD 45 orang didapatkan hasil untuk umur kehamilan $\geq 42$ minggu berjumlah 4 orang $(8,9 \%)$ dan untuk umur kehamilan < 42 minggu berjumlah 41 orang $(91,1 \%)$. Dan untuk kejadian tidak IUFD menunjukkan untuk umur kehamilan $\geq 42$ minggu berjumlah 5 orang $(11,1 \%)$ dan $<42$ minggu berjumlah 40 orang $(88,9 \%)$. Dalam hal ini dapat dilihat presentase umur kehamilan $<42$ minggu lebih banyak dibandingkan dengan $\geq 42$ minggu. Menurut teori mengatakan bahwa salah satu penyebab dari IUFD dari faktor maternal adalah kehamilan postterm $(\geq 40)$. Karena pada umur kehamilan kehamilan post term fungsi plasenta yang sudah mulai menurun setelah 42 minggu sehingga mengakibatkan suplai oksigen dari ibu ke janin terganggu dan terjadi peningkatan gawat janin bahkan kematian.

Dari hasil uji statistik menggunakan uji Chi-square yaitu untuk melihat hubungan umur kehamilan dengan kejadian IUFD didapatkan hasil $\rho$ value $=1,000(>0,05)$. Ini berarti tidak terdapat hubungan antara umur ibu dengan kejadian IUFD.

\section{Hubungan Faktor Kadar Hb Dengan Kejadian IUFD}

Berdasarkan hasil penelitian berdasarkan kadar Hb, dari 90 sampel dengan kejadian IUFD 45 orang menunjukkan kadar $\mathrm{Hb}<11$ gr \% (anemia) berjumlah 12 orang $(26,7,5 \%$ ) dan untuk kadar $\mathrm{Hb} \geq 11$ gr $\%$ (tidak anemia) berjumlah 33 orang $(73,3 \%)$. Sedangkan untuk kejadian tidak IUFD dari 90 orang terdapat untuk kadar $\mathrm{Hb}<11$ gr \% berjumlah 16 orang (35,5\%) dan kadar $\mathrm{Hb} \geq 11$ gr \% berjumlah 29 orang $(64,5 \%)$.

Dari analisa data tersebut menunjukkan bahwa ibu hamil yang tidak anemia lebih banyak dibandingkan dengan ibu hamil yang anemia. Anemia defisiensi zat besi merupakan salah satu gangguan yang paling sering terjadi selama kehamilan. Kekurangan zat besi dapat menimbulkan gangguan pada pertumbuhan janin karena kurangnyaasupan gizi dari ibu ke bayi.

Dari hasil uji statistik menggunakan uji Chi-square yaitu untuk melihat hubungan kadar Hb dengan kejadian IUFD didapatkan hasil $\rho$ value $=0,010(<0,05)$. Ini berarti terdapat hubungan yang signifikan antara kadar $\mathrm{Hb}$ dengan kejadian IUFD, dengan Odds Ratio $(\mathrm{OR})=2,309$ artinya ibu yang mengalami anemia mempunyai risiko 2,3 kali mengalami IUFD. Hal ini mendukung teori yang dikemukakan bahwa anemia pada ibu hamil dapat mengakibatkan terjadinya bahaya terhadap janin yaitu: Abortus, kematian intra uteri, persalinan premature, berat badan lahir rendah (BBLR), dapat terjadi cacat bawaan

Dari ketiga variabel yang diteliti yaitu umur ibu, umur kehamilan dan kadar $\mathrm{Hb}$, hanya satu variabel yang mempunyai hubungan signifikan terhadap kejadian IUFD yaitu kadar $\mathrm{Hb}$. Untuk itu perlu dilakukan penelitian lanjut untuk mencari faktor-faktor penyebab terjadinya kejadian IUFD.

\section{CONCLUSION}

1. Distribusi frekuensi umur ibu paling banyak pada usia tidak berisiko (20-35 tahun). Dan setelah dilakukan uji statistik Chi-square tidak ada hubungan antara umur ibu dengan kejadian IUFD di RSU Imelda Medan Tahun 2020.

2. Distribusi frekuensi umur kehamilan paling banyak pada umur kehamilan < 42 minggu. Dan hasil uji statistik Chi-square tidak ada hubungan yang signifikan antara umur kehamilan dengan kejadian IUFD di RSU Imelda Medan Tahun 2020. 
3. Distribusi frekuensi kadar $\mathrm{Hb}$ paling banyak pada kadar $\mathrm{Hb} \geq 11$ gr\% (tidak anemia). Dan hasil uji statistik Chi- square terdapat hubungan yang signifikan antara kadar $\mathrm{Hb}$ dengan kejadian IUFD di RSU Imelda Tahun 2020.

4. Faktor-faktor yang berhubungan dengan kejadian IUFD di RSU Imelda Medan pada tahun 2020 dari ketiga variabel yang diteliti yaitu umur ibu, umur kehamilan dan kadar $\mathrm{Hb}$, hanya satu variabel yaitu Kadar $\mathrm{Hb}$ yang mempunyai hubungan signifikan dengan kejadian IUFD.

\section{REFERENCES}

Saifuddin, A. B. 2010. Buku Panduan Praktis Pelayanan Kesehatan Maternal dan Neonatal. Jakarta: Bina Pustaka Sarwono Prawiroharjo.

Kementrian Kesehatan RI. Profil Kesehatan Indonesia. 2012. [cited 201220 April]; Diakses dari: http://www.kemkes.go.id.

Dinas Kesehatan Propinsi Sulawesi Utara. Profil Data Kematian Neonatal, Bayi dan Anak Balita Tahun 2013. Manado: Dinas Kesehatan Prov. Sulut 2014.

Luqyana, S. D., Rodiani, \& Prabowo, A. Y. 2017. Intrauterine Fetal Death: Usia Maternal sebagai Salah Satu Faktor Risiko Intrauterine Fetal Death : Maternal Age as One of The Risk Factors. Medula, 7(5), 25-29. http://repository.lppm.unila.ac.id/7253/1/intrauterine fetal death.pdf.

Nugroho, T. 2012. Obstetri dan Ginekologi: Untuk Kebidanan dan Keperawatan. Yogyakarta: Nuha Medika.

Manuaba, I. B. G, Manuaba IAC, Manuaba IBGF. 2012. Pengantar Kuliah Obstetri. Jakarta: EGC.

Wiknjosastro, G. H. 2007. Ilmu Kebidanan. Jakarta: Yayasan Bina Pustaka Sarwono Prawiroharjo.

Waryono. 2010. Gizi Reproduksi. Yogyakarta: Pustaka Rihama.

\section{BIOGRAPHIES OF AUTHORS}

\begin{tabular}{l|l|} 
Elvalini Warnelis Sinaga, Gelar D-III diperoleh dari Akademi Kebidanan Imelda \\
Medan, Jurusan Kebidanan pada tahun 2009. Gelar Sarjana diperoleh dari Poltekes \\
Kemenkes RI Medan, Jurusan Bidan Pendidik Tahun 2011. Magister Kesehatan \\
diperoleh dari Universitas Sumatera Utara, Jurusan Kesehatan Reproduksi pada tahun \\
2018. Saat ini aktif sebagai dosen tetap di Prodi D-III Kebidanan Universitas Imelda \\
Medan dan menjabat sebagai Sekretaris Prodi.
\end{tabular}

